\title{
Caring for the Earth for better health and well-being of all: addressing climate change as a planetary health emergency
}

\section{James Hospedales ${ }^{a}$}

${ }^{a}$ MD, MSc, former Director of Caribbean Public Health Agency (CARPHA), and founder of EarthMedic/EarthNurse.

\section{Introduction}

Most of the major public health problems with which I have wrestled in my life - epidemics and pandemics, natural disasters, and chronic noncommunicable diseases (NCDs) - are all symptomatic of, or related to, climate change and/or destruction of the environment. As a Christian, the roots lie in lack of respect for our Creator and lack of reverence for the goodness and inter-dependence of all of creation.

Climate change is a public health crisis because it is destroying the conditions for life. The unprecedented, deadly heatwaves in the Pacific Northwest of the United States are a current example. "Patient Earth" is showing many signs of ill-health, particularly the increasing global temperature after thousands of years of stability, caused mainly by human activities (Figure 1). ${ }^{1}$

Figure 1. Global land temperature index

Data source: NASA's Goddard Institute for Space Studies (GISS). Credit: NASA/GISS

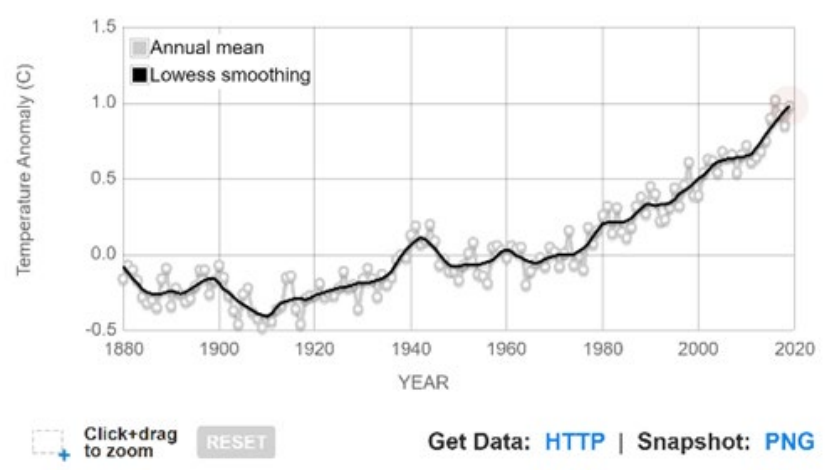

Source: NASA. Climate Change: Vital Signs of the Planet (https://climate.nasa.gov/vital-signs/globaltemperature/)
Though natural cycles have altered Earth's climate previously, current global warming is mainly attributable to human activity - specifically to burning of fossil fuels such as coal, oil, gasoline, and natural gas (particularly with the advent of globalized industrialization), causing a stronger greenhouse effect ${ }^{2}$ with atmospheric carbon dioxide levels now at $419 \mathrm{ppm}$, the highest in 4 million years. ${ }^{3}$ The implications are profound for the health and wellbeing of people, economies, and the planet.

In response, 196 countries joined in the United Nations Convention for Climate Change in 2015 with the aim of limiting global warming to well below 2, preferably 1.5, degrees Celsius, compared to preindustrial levels. ${ }^{4}$ The G7/G20 and others have long recognised the vulnerability of Small Island and lowlying Developing States (SIDS) to the adverse impacts of climate change, including food insecurity $^{6}$, population displacement, and forced migration. $^{7} \quad$ Faith community partnerships have started to take a role in addressing these issues for the Pacific SIDS, which highlights opportunities to address climate-related global health risks in other regions. ${ }^{8}$

\section{Bearing Witness}

In my observation of the environment in Trinidad and the Caribbean for $50+$ years, across "climate timescales," I have seen continued degradation of natural systems, with many direct and indirect health impacts. As a boy in Trinidad, we had sea grass beds and clear seawater; then seagrass beds became barren mudflats, the fiddler crabs disappeared, there were far fewer fish, and the water grew turbid. Much of the coastline became polluted 
from the oil and gas industry, and plastic waste choking drains and rivers contributed to worsening floods, littering coasts, and harming wildlife.

The weather has become hotter and drier in Trinidad and Tobago (0.7 degrees Celsius increase from 1990 to 2019). ${ }^{9}$ Near-annually, human-made forest fires last longer and spread further, destroying some 300,000 acres of forest, wildlife, property and sometimes, lives. ${ }^{10}$ The damaged watersheds contribute to worse floods during the rainy season, undermining agriculture, and food security ${ }^{11}$, and increasing the risk for vector borne diseases. Record floods in October 2018 effectively cut Trinidad in half, resulting in temporary disruption in access to health and other essential services.

As coordinator of chronic disease prevention and control in the Pan American Health Organization (PAHO) 2006-2012, I could discern that the costly epidemics of NCDs - cardiovascular diseases, diabetes, chronic respiratory diseases, and cancerhad similar associations with climate change. For example, fossil fuel-dependent, mechanised agriculture, and motorised transport contribute to greenhouse gas emissions, and pollution as well as sedentariness, unhealthy diets, and obesity, major risk factors for the burdensome NCDs.

\section{Epidemics and Extreme Weather}

As inaugural Director of the Caribbean Public Health Agency (CARPHA) ${ }^{12}$, I was faced with two new arboviral disease epidemics, Chikungunya ${ }^{13}$ and $\mathrm{Zika}^{14}$ viruses, in 2014 and 2016, respectively, the latter declared by WHO as a Public Health Emergency of International Concern (PHEIC). The Aedes aegypti mosquito vector thrives in breeding sites in water drums, discarded tires, etc., and warming weather is projected to increase its invasive potential. ${ }^{15}$ At the same time, we faced "slow-moving disasters" such as increasing childhood obesity, an unhealthy food environment - high in sugar, animal fats, salt and calories-and a loss of use of sustainably grown, indigenous crops. These and

July 2021. Christian Journal for Global Health 8(1) other conditions compound adverse health impacts of climate change.

Focusing the science to the Caribbean ${ }^{16}$, we are to expect hotter, drier weather, overall; with longerlasting Category $4 / 5$ super storms and inundations of rain. As Epidemiologist at the Caribbean Epidemiology Centre (CAREC) 1987-1993 and on the PAHO/WHO Caribbean disaster response team, we mobilised after major hurricanes, e.g., Gilbert, Hugo, in the late 80 s and early 90s. Over the almost three decades since, I've seen that hurricanes have become more frequent and destructive. From Hurricane Matthew in 2015, the longest-lived Category 4/5 hurricane; to the triple-whammy of Hurricanes Jose, Irma, and Maria in 2017, that destroyed $225 \%$ of Dominica's GDP, damaging health facilities and severely affecting health determinants such as water and sanitation; to the slow-moving hurricane Dorian, that ravaged the Bahamas; to the wild Atlantic hurricane 2020 season with a record 30 named storms; we are living in an era of consequences.

\section{Theological Reflections}

I believe science gives us tools to better glimpse the amazing nature of God, and the Earth as a delicately balanced, living system, which we are only just beginning to comprehend. In Genesis, the opening book of the Bible, God said "it was good" five times as the Earth, seas, plants, animals, and humans were created. Yet, we are not being good stewards over what we have been given charge (Gen 1:28). Global populations of mammals, birds, fish, reptiles, and amphibians have dropped by $68 \%$ between 1970 and 2016. Insects, trees and forestspart of the whole web of life-are also being threatened on an unprecedented scale with irreplaceable biodiversity loss. ${ }^{17}$ Much of this is driven by human overconsumption, population growth and intensive agriculture, according to a major new assessment of the abundance of life on Earth. ${ }^{18}$ This situation has stimulated much theological reflection worldwide, including the Papal 
encyclical of 2015, "On care for our common home." 19

If God made the Earth and everything in it and saw that "it was good" and commissioned the first humans to have responsible dominion of the whole creation, does the lack of respect, exploitation, and neglected care for nature offend God? Two themes can be discerned in the Old and New Testaments: respect for the Creator and respect for the interdependence of creation. Psalm 104 echoes the goodness of all of creation and the inter-dependence of creation, the cycle of life, and the responsibility of people to manage their environment. Romans 1:1920 speaks of the wonder of creation being a manifestation of God's power and divine nature, so that those who fail to glorify him in practicing this dual respect for God and nature are "without excuse."

Gus Speth, co-founder of the NRDC and CEO of the UN Development Program, had some insights worthy of consideration:

I used to think that top environmental problems were biodiversity loss, ecosystem collapse and climate change. I thought that thirty years of good science could address these problems. I was wrong. The top environmental problems are selfishness, greed and apathy, and to deal with these we need a cultural and spiritual transformation. ${ }^{20}$

\section{Conclusion}

A lifetime of environmental observations, my scientific and medical training, my engagement with the public sector, and my faith in God all point to the conclusion that the Earth is sick and "dying" as we face the $6^{\text {th }}$ great extinction crisis, traced mostly to human activities. ${ }^{21}$ Only with an unprecedented coming together of diverse partners, including the faith community, to care for our common home can we maintain our life support systems, see the world transformed, and protect the most vulnerable in our societies.
The signs and symptoms of an ailing Earth in 2020/21 are myriad: Record heat and CO2 levels, with drought, population displacement and migration; extensive wildfires - e.g., Australia, Brazil, California; wild Atlantic hurricane and Pacific typhoon seasons; major floods in China; irreplaceable bio-diversity loss; and loss of the Arctic ice shield, our planet's air conditioning system. ${ }^{22}$ How can we regain and foster hope and see healing in our ailing world?

Addressing climate change can have many benefits for population health. Based on decades of research, The Lancet in 2018 published a review which stated that while climate change was the greatest threat to public health, addressing climate change could be the "greatest global health opportunity of the $21^{\text {st }}$ century," 23 as climate action at scale has immediate health co-benefits.

As an epidemiologist, I worry that we have no controls; that we do not know what happens to a planet exposed to such widespread insults, since we have not been here before. This editorial therefore issues a call to all doctors, nurses, faith leaders, and public health professionals to awaken to the climate and health crisis at hand; get better informed and then act to improve the health of individuals, society, and the planet to avoid a catastrophe. God made the world and everything in it, and remarked upon the goodness of all of creation, interdependent for their lives and livelihoods, but corrupted at the core. God's work is to make all things new and to establish justice and peace. He asks us to join in that objective. In serving God and caring for others and the environment, there is no conflict.

We must recognize the importance of human activity both to draw down or to build up human and planetary health. In many ways, we are exceeding the amazing regenerative capacity of the underlying natural systems on which our health and well-being, lives and livelihoods depend. In order to restore the balance and to mitigate catastrophe, aligning with divine objectives and seeking His participation is a good starting place. 
"May God give us the grace to come together in one accord to care for all that He has created."

EarthNurse Candace Scofield, Trinidad.

\section{References}

1. Intergovernmental Panel on Climate Change. IPCC Fifth Assessment Report [Internet]; 2014. Available from: https://www.ipcc.ch/site/assets/uploads/2018/02/AR5 SYR FINAL_SPM.pdf

2. NASA. The causes of climate change. Global climate change: Vital signs of the planet. [Internet] Available from https://climate.nasa.gov/causes/

3. NOAA Research News. Carbon dioxide peaks near 420 parts per million at Mauna Loa observatory [Internet]; 2021 June 7. Available from: https://research.noaa.gov/article/ArtMID/587/ArticleI $\mathrm{D} / 2764 /$ Coronavirus-response-barely-slows-risingcarbon-dioxide

4. United Nations Climate Change. The Paris Agreement [Internet]; 2016. Available from:

https://unfccc.int/process-and-meetings/the-parisagreement/the-paris-agreement

5. United Nations Climate Change. Global Climate Action Pathway Finance Vision and Summary [Internet]; 2021. Available from: https://unfccc.int/sites/default/files/resource/Finance Vision\%26Summary.pdf

6. Lenderking HL, Robinson S, Carlson G. Climate change and food security in Caribbean small island developing states: challenges and strategies. International Journal of Sustainable Development \& World Ecology. 2020 Aug 11;28(3):238-245. https://doi.org/10.1080/13504509.2020.1804477

7. Julca A, Paddison O. Vulnerabilities and migration in Small Island Developing States in the context of climate change. Nat Hazards. 2010;55:717-728. https://doi-org.online.uchc.edu/10.1007/s11069-0099384-1

8. Mitchell R B, Grills N J. A historic humanitarian collaboration in the Pacific context. Christ J Global Health. 2017 Jul;4(2):87-94. https://doi.org/10.15566/cjgh.v4i2.160

9. World Data.info. The climate in Trinidad and Tobago. [Internet]. Available from: https://www.worlddata.info/america/trinidad-andtobago/climate.php
10. Rampersad S. Destruction of the Northern Range between 1987-2018 . . 276,000 acres ravaged by fire [Internet]. Trinidad \& Tobago Guardian. 2021 Jul 26. Available from:

https://www.guardian.co.tt/news/destruction-of-thenorthern-range-6.2.802110.0bc76ef0b3

11. Eitzinger A, Farrell A, Rhiney K, Camona S, van Loosen I, Taylor M. Trididad \& Tobago: Assessing the impact of climate change on cocoa and tomato [Internet]. International Center for Tropical Agriculture Policy Brief No. 27. December 2015. Available from: https://cdkn.org/wpcontent/uploads/2014/04/CIAT_PB27_TRINIDADAND-TOBAGO-ASSESSING-THE-IMPACT-OFCLIMATE-CHANGE-ON-COCOA-ANDTOMATO.pdf

12. Hospedales CJ. Caribbean public health: achievements and future challenges. The Lancet Public Health. 2019 July 1;4(7):E324. https://doi.org/10.1016/S2468-2667(19)30102-1

13. Olowokure B, Francis L, Polson-Edwards K, Nasci R, Quénel R, Aldighieri S, Rousset D, Gutierrez C, Ramon-Pardo P, dos Santos T, Hospedales CJ. The Caribbean response to chikungunya. The Lancet Infectious Diseases. 2014 Nov 11;4(11):1039-1040. https://doi.org/10.1016/S1473-3099(14)70948-X

14. Francis L, Hunte S-A, Valadere AM, Polson-Edwards $\mathrm{K}$, Asin-Oostburg V, Hospedales CJ. Zika virus outbreak in 19 English- and Dutch-speaking Caribbean countries and territories, 2015-2016. Revista Panamericana De Salud Pública. 2018;42: E120.

15. Iwamura T, Guzman-Holst A, Murray K. Accelerating invasion potential of disease vector Aedes aegypti under climate change. Nature Commun. 2020;11: 2130. https://doi.org/10.1038/s41467-020-16010-4

16. London JB. Implications of climate change on small island developing states: experience in the Caribbean region. Journal of Environmental Planning and Management. 2007 Jan 22;47(4):491-501. https://doi.org/10.1080/0964056042000243195

17. Greenfield P. Humans exploiting and destroying nature on unprecedented scale - report [Internet]. The Guardian. 2020 Sept 9. Available from: https://www.theguardian.com/environment/2020/sep/ 10/humans-exploiting-and-destroying-nature-onunprecedented-scale-report-aoe 
18. Almond REA, Grooten M, Petersen T. (Eds). Living Planet Report 2020 - Bending the curve of biodiversity loss [Internet]. WWF, Gland, Switzerland. 2020. Available from: https://www.wwf.org.uk/sites/default/files/202009/LPR20 Full report.pdf

19. Francis. Encyclical letter LAUDATO SI' of the Holy Father Francis on the care for our common home. [Internet] 2015. Available from: https:/www.vatican.va/content/francesco/en/encyclic als/documents/papa-francesco_20150524_enciclicalaudato-si.html

20. Speth G. Gus Speth calls for a new environmentalism [audio program]. Living on Earth; 2016 May 5. Available from: https://loe.org/shows/segments.html?programID $=15$ $\underline{\mathrm{P} 13-00007 \& \text { segmentID }=6}$
21.N Ceballos G, Ehrlich PR, Raven PH. Vertebrates on the brink as indicators of biological annihilation and the sixth mass extinction. Proceedings of the National Academy of Sciences. 2020 Jun;117(24):1359613602. https://doi.org/10.1073/pnas. 1922686117

22. Nuccitelli D, Masters J. The top 10 weather and climate events of a record-setting year [Internet]. Yale Climate Connection. 2020 Dec 21. Available from: https://yaleclimateconnections.org/2020/12/the-top10 -weather-and-climate-events-of-a-record-settingyear/

23. Watts N, Amann M, Ayeb-Karlsson S, Belesova K, Bouley T, Boykoff M, et.al. The Lancet countdown on health and climate change: from 25 years of inaction to a global transformation for public health. The Lancet 2018 Feb 10-16;391(10120):581-630. https://doi.org/10.1016/S0140-6736(17)32464-9

Submitted: 15 July 2021, modified 28 July 2021, accepted 29 July 2021, published 30 Dec 2021

Competing Interests: None declared.

Correspondence: Dr. James Hospedales, Trinidad \& Tobago jameshospedales@earthmedic.com

Cite this article as: Hospedales CJ. Caring for the Earth for better health and well-being of all: addressing climate change as a planetary health emergency. Christ J Global Health. July 2021; 8(1):3-7. https://doi.org/10.15566/cjgh.v8i1.575

(C) Author. This is an open-access article distributed under the terms of the Creative Commons Attribution License, which permits unrestricted use, distribution, and reproduction in any medium, provided the original author and source are properly cited. To view a copy of the license, visit http://creativecommons.org/licenses/by/4.0/

\section{cjgh.org}

